\title{
Repercussions of the pandemic on the health of Brazilian Children beyond Covid-19
}

\section{| ${ }^{1}$ Aisiane Cedraz Morais, ${ }^{2}$ Juliana de Oliveira Freitas Miranda |}

\author{
${ }^{1}$ Departamento de Saúde, Universidade Estadual de Feira de Santana. Feira de Santana-BA, Brasil (aisicedraz@hotmail.com). \\ ORCID: 0000-0001-9547-6914. \\ 2 Departamento de Saúde, Universidade Estadual de Feira de Santana. Feira de Santana-BA, Brasil (julidefreitas@hotmail.com). \\ ORCID: 0000-0001-7659-3103.

The contemporary world has experienced, in recent months, a pandemic context caused by the SARS-CoV-2 virus that appeared in Wuhan City, China, in late December 2019 (ZHU et al., 2020). The first cases were referred to as an outbreak of pneumonia of unknown origin that could be associated with a severe acute respiratory syndrome. It was soon confirmed that it was an infectious disease caused by a new type of coronavirus (ZHU et al., 2020; LU et al., 2020).

The highest mortality rates of the disease caused by SARS-CoV-2, Corona Virus Disease 2019 (COVID-19), have been mostly associated with elderly patients or the presence of comorbidities that potentiate a severe condition of the disease. The clinical spectrum of human infection is not yet fully established, and it is not possible to accurately determine the pattern of lethality, mortality, infectivity and transmissibility (BRASIL, 2020a). However, from studies on COVID-19 in the pediatric age group, it is a consensus to affirm that, in the vast majority of children, the disease has been asymptomatic or with mild to moderate symptoms (VILELAS, 2020; DONG et al., 2020; REHMAN et al., 2020).

Although child ren do not present a higher risk for the severe form of COVID-19, the pandemic has important repercussions for different Brazilian childhoods, 
with unintended consequences for the health and well-being of this population, especially those with greater social vulnerability, those with chronic diseases and/ or special conditions.

In this text we propose a reflection on the repercussions of the pandemic on the health of Brazilian children, advancing a little beyond the clinical aspects of the disease. However, we highlight that it will not be possible to exhaust this discussion, since these impacts will behave differently in each childhood, considering their particularities and the context where they live.

The arrival of the new virus has put to the test how each country faces the pandemic, what health resources it is using to contain the disease, as well as what strategies it adopts to care for those affected. For Werneck and Carvalho (2020), in Brazil, the challenges are even greater, considering the context of social inequality, with populations living in precarious housing and sanitation conditions, without systematic access to water and in agglomeration situation.

Brazil, like all countries experiencing the pandemic, has adopted measures to contain the spread of the virus and prevent the health system from collapsing due to the exponential growth of cases. Among the main precautionary measures are the isolation of cities, the closure of establishments, including schools, and the suspension of public transport, with the adoption of different protocols depending on each region (VENTURA; AITH; RACHED, 2020).

Wong et al. (2020) highlight that the suspension of face-to-face activities in schools, social distancing, the reduction of health services (e.g., cancellation non-urgent consultations) and ubiquitous public health messages are some of the measures aimed at delaying of contamination by COVID-19. In particular, children from families with low socioeconomic status probably present a higher risk for new or aggravating problems, highlighting the critical role of risk mitigation strategies for these families.

The United Nations Children's Fund (UNICEF, 2020) highlights the indirect effects of the pandemic on children by estimating that: 1.8 billion (77\%) of the 2.35 billion children under the age of 18 worldwide living in one of 132 countries with home stay policies since the beginning of May; in 177 countries, almost 1.3 billion students (more than $72 \%$ ) are out of school due to their closure; $40 \%$ of the world's population cannot wash their hands with soap and water at home; and even more than 117 million children in 37 countries may miss measles vaccination in the first 
half of 2020, as the pandemic has hampered immunization campaigns, either due to the absence of such or low demand for basic health units.

UNICEF (2020) also highlights the negative interference of the pandemic on children's eating standards, considering that in 143 countries, nearly 370 million children typically rely on school meals to obtain a reliable source of daily nutrition, and now need to look for other food sources while schools are closed. Reporting UNICEF data to the Brazilian reality, according to the 2019 School Census (BRASIL, 2020b), Brazil has almost 39 million children and adolescents enrolled in the public primary education network, and may depend on school meals to complement or guarantee daily food, compromised by the suspension of classes at that time.

The pandemic can still expose Brazilian children, unequally, to a higher risk of morbidity and mortality from preventable diseases, since the discontinuity of routine vaccination can increase susceptibility and the likelihood of outbreaks of vaccinepreventable diseases, such as measles, influenza, among other immunopredictable diseases (SBIM, 2020). In addition, the absence of a healthy daily diet can increase cases of malnutrition.

Thus, risk mitigation strategies during social distancing measures need to be adopted. Each country should assess its epidemiological risks, as well as offer structural conditions in its health system to carry out vaccination safely (SBIM, 2020), and also ensure the feeding of children during the removal from the public school system (BRASIL, 2020b).

Also on the impacts of the suspension of school activities, it is necessary to reflect on the difficulties in offering remote activities to children and adolescents students of the public school system. In many locations in Brazil there is an abyss between the quality of public and private education, in addition to the lack of access to the Internet, situations that were evident at that time. While private schools have offered remote education to their students to ensure minimal access to education during the pandemic, students from public schools in many Brazilian states have been without classes since the beginning of social distancing measures.

Although the benefits of social distancing are well established by reducing the risk of transmission of SARS-CoV-2, these measures can have more harmful consequences for children's health.

Among the emotional reactions and behavioral changes frequently presented by children during the pandemic, Marin et al (2020) highlight the difficulties of 
concentration, irritability, fear, restlessness, boredom, feeling of loneliness, changes in sleep pattern and diet; which are expected manifestations within the current context. Thus, the importance of understanding the social and family scenario of each child is reinforced in order to adequately meet their individual needs.

Still, reports of increased domestic violence after quarantine orders in China revealed the risks of isolation for interpersonal violence. A review of the psychological impact of quarantine published in The Lancet (ROBERTON et al., 2020) indicated increased anger, confusion and symptoms of post-traumatic stress, as well as evidence of increased substance use in quarantined people. These types of unregulated emotions and substance use can increase violent behavior, especially within the family.

With social distancing, the increase in the time of coexistence and tensions in interpersonal relationships are factors that, according to Marques et al (2020) can make more frequent episodes of violence against children and adolescents in this period. Furthermore, Roberton et al (2020) report that children's exposure to intimate partner violence, witnessed directly or heard, is harmful and can lead to posttraumatic stress disorder and other emotional and behavioral problems. In typical (i.e. non-pandemic) circumstances, child abuse rates are alarming.

From the above, the COVID-19 pandemic unveils a crisis of children's rights, a crisis that, in order to guarantee life in sometimes minimal conditions, denies the right to come and go, access to health services, education, food, sociability, culture and, in some situations, the right of family life, all provided for in the Statute of children and adolescents as essential rights (BRASIL, 2017).

We hope that overcoming this pandemic, to the extent that it exposes so clearly so many inequalities, can not only expose the susceptibility of the vulnerable; above all, demand public policies for repair and mitigation of risks. ${ }^{1}$

\section{References}

BRASIL. Ministério da Saúde. Secretaria de Vigilância em Saúde. Centro de Operaçóes de Emergências em Saúde Pública (COE-nCoV). Boletim Epidemiológico. Brasília, n. 1, jan. 2020a. Available at: <https://portalarquivos2.saude.gov.br/images/pdf/2020/janeiro/28/Boletimepidemiologico-SVS-28jan20.pdf>. Retrieved: 25 May 2020.

BRASIL. Agência Senado. Nova leigarante alimentos da merenda escolar a alunos sem aula. Brasília, 8 abr. 2020. 2020b. Available at: <https://www12.senado.leg.br/noticias/materias/2020/04/08/ nova-lei-garante-alimentos-da-merenda-escolar-a-alunos-sem-aula>. Retrieved: 27 May 2020. 
BRASIL. Lei no 8.069, de 13 de julho de 1990. Dispóe sobre o Estatuto da Criança e do Adolescente e dá outras providências. Available at: <http://www.planalto.gov.br/ccivil_03/leis/ 18069.htm>. Retrieved: 27 May 2020.

DONG, Y. et al. Epidemiological characteristics of 2143 pediatric patients with 2019 coronavirus disease in China. Pediatrics. 2020. DOI: 10.1542/peds.2020-0702. Available at: https://pediatrics.aappublications.org/content/pediatrics/early/2020/03/16/peds.2020-0702. full.pdf. Retrieved 20 June 2020.

LU, R. et al. Genomic characterisation and epidemiology of 2019 novel coronavirus: implications for virus origins and receptor binding. Lancet, v. 395, n. 8, p. 565-574, 2020. DOI: 10.1016/ S0140-6736(20)30251-8. Available at: <https://www.thelancet.com/pdfs/journals/lancet/ PIIS0140-6736(20)30251-8.pdf>. Retrieved: 21 May 2020.

MARIN, A. et al. Saúde Mental e Atenção Psicossocial na Pandemia COVID-19: crianças na pandemia COVID-19. Rio de Janeiro: Fiocruz/CEPEDES, 2020. 20 p. Available at: <https://www.arca.fiocruz.br/bitstream/icict/41713/2/crianc\%cc\%a7as_pandemia.pdf>. Retrieved: 26 Oct 2020.

MARQUES, E. S. et al. A violência contra mulheres, crianças e adolescentes em tempos de pandemia pela COVID-19: panorama, motivaçóes e formas de enfrentamento. Cad. Saúde Pública, v. 36, n. 4, p. e00074420, 2020. Available at: <http://www.scielo.br/scielo. php?script=sci_arttext\&pid=S0102311X2020000400505\&lng=en\&nrm=iso >. https://doi. org/10.1590/0102-311x00074420. Retrieved: 26 Oct 2020.

MENENDEZ, C. et al. Avoiding indirect effects of COVID-19 on maternal and child health. The Lancet Global Health. May 12, 2020. Available at: <https:/www.thelancet.com/journals/ langlo/article/PIIS2214-109X(20)30239-4/fulltext>. DOI: https://doi.org/10.1016/S2214109X(20)30239-4. Retrieved: 25 jun. 2020.

REHMAN, S. et al. Current scenario of COVID-19 in pediatric age group and physiology of immune and thymus response. Saudi Journal of Biological Sciences, 2020. Available at: https://www.sciencedirect.com/science/article/pii/S1319562X20301923. DOI: https://doi. org/10.1016/j.sjbs.2020.05.024. Retrieved 20 June 2020.

ROBERTON, T. et al. Early estimates of the indirect effects of the COVID-19 pandemic on maternal and child mortality in low-income and middle-income countries: a modelling study. The Lancet Glob Health. 2020 doi: 10.1016/S2214-109X(20)30229-1. Available at https://www. ncbi.nlm.nih.gov/pmc/articles/PMC7217645/ Retrieved: 25 jun. 2020.

SOCIEDADE BRASILEIRA DE IMUNIZAÇÕES. Vacinação de rotina durante a pandemia de COVID-19. Informe Técnico, 9 abr. 2020. Available at https://sbim.org.br/images/files/notastecnicas/nota-tecnica-sbim-vacinacao-rotina-pandemia.pdf>. Retrieved: 27 May 2020. 
UNICEF. As COVID-19 devastates already fragile health systems, over 6,000 additional children under five could die a day, without urgent action. Available at: <https://www.unicef. org/press-releases/covid-19-devastates-already-fragile-health-systems-over-6000-additionalchildren>. Retrieved: 26 May 2020.

VENTURA, D. F. L.; AITH, F. M. A.; RACHED, D. H. A emergência do novo coronavírus e a "lei de quarentena" no Brasil. Revista Direito e Práxis. Ahead of print, Rio de Janeiro, 2020. DOI: 10.1590/2179-8966/2020/49180. Available at: <https://www.e-publicacoes.uerj.br/index. php/revistaceaju/article/view/49180/32876>. Retrieved: 26 May 2020.

VILELAS, J.M.S. O novo coronavírus e o risco para a saúde das crianças. Rev. LatinoAm. Enfermagem [online]. 2020, vol.28, e3320. Available at: <http://www.scielo.br/scielo. php?script=sci_arttext\&pid=S0104-11692020000100202\&lng=en\&nrm=iso $>$ Epub Apr 22, 2020. ISSN 1518-8345. https://doi.org/10.1590/1518-8345.0000.3320. Retrieved: 27 May 2020.

ZHU N. et al. A Novel Coronavirus from Patients with Pneumonia in China, 2019. The New England Journal of Medicine, v. 382, n. 8, p. 727-733, 2020. DOI: 10.1056/NEJMoa2001017. Available at: https://www.nejm.org/doi/pdf/10.1056/NEJMoa2001017. Retrieved: 21 May 2020.

WERNECK, G. L.; CARVALHO, M. S. A pandemia de COVID-19 no Brasil: crônica de uma crise sanitária anunciada. Cad. Saúde Pública, v. 36, n. 5, p. e00068820, 2020. Available at: $<$ http://cadernos.ensp.fiocruz.br/csp/artigo/1036/a-pandemia-de-covid-19-no-brasil-cronicade-uma-crise-sanitaria-anunciada $>$. http://dx.doi.org/10.1590/0102-311X00068820. Retrieved: 27 May 2020.

WONG, C. A. et al. Mitigating the impacts of the COVID-19 pandemic response on atrisk children. Pediatrics, 2020. Available at: https://pediatrics.aappublications.org/content/ pediatrics/early/2020/04/17/peds.2020-0973.full.pdf. doi: 10.1542/peds.2020-0973. Retrieved: 26 May 2020.

\section{Note}

${ }^{1}$ A. C. Morais and J. O. F. Miranda were responsible for the design, writing of the text and final approval of the version to be published. 